$3 \frac{1}{2}$ months (April 10 to July 23). Improvement followed treatment by the end of August. In November recrudescence of inflammation occurred and glaucoma supervened. Excision of the eye was advised.

Surely this is a case above all others in which facts, if obtainable, are required. If enucleation of the eye has been carried out, I am sure that many of your readers would like to know the result of the histological examination. If this is unobtainable, I expect that many besides myself will prefer to regard " $\mathrm{Mr}$. T. L., aged 69, a feeble, worn-looking man," whose doctor gave his opinion that he was "completely worn out and has been a heavy drinker" as the subject of irido-cyclitis with secondary glaucoma, diue to some undefined cause other than sympathetic ophthalmitis. In support of this view, may I quote Mr. Harrison Butler's original article :on p. 548 he says "before we can make a diagnosis (of sympathetic ophthalmitis) we must satisfy ourselves .... that there is no other extraneous cause for the inflammation in the sympathising eye."

$$
\text { I am, Sirs, }
$$

Yours faithfully,

$$
\text { HUMPHREY NEAME. }
$$

21, DEVONSHIRE PLACE, W.1

February 1, 1943.

\title{
OBITUARY
}

\section{PERCIVAL JOHN HAY}

OPHTHALMOLOGISTS throughout the world will read with regret of the death of Dr. P. J. Hay, of Sheffield.

Percival John Hay was born on June 28, 1875 at Basle, Switzerland. His father was John Hay, a Scotsman, who became Professor of English in Basle University, and his mother was from the Manchester district of Lancashire. Hay was educated at Basle and before commencing Medicine at Edinburgh he was for a year an undergraduate at Basle University. He graduated M.B., Ch.B. Edin. in 1901, and M.D. with high commendation three years later. He held .Resident appointments at the Birmingham and Midland Ear and Throat Hospital and the Birmingham and Midland Eye Hospital, after which, in 1908 he started practice in Sheffield as an Ophthalmic Surgeon, and for a time acted as Clinical Assistant to the late Simeon Snell at the Sheffield Royal Infirmary. He was appointed Honorary Ophthalmic Surgeon to the Beckett's Hospital, Barnsley, in 1910, Honorary Ophthalmic Surgeon to the Sheffield Royal Hospital in 1916, and at about the same time, Ophthalmic Surgeon to the Sheffield Education Committee. 
During the 1914-18 War he served as Captain in the R.A.M.C. and was for some time Ophthalmic Specialist to the Cambridge Hospital, Aldershot. At the commencement of the present hostilities he immediately went back into hard hospital practice in order to relieve a colleague who had been mobilized. There is no doubt that the extra work which he put in during the last three years contributed in no small measure to the illness which caused his death.

It was just before the outbreak of War in 1914 that Hay, in association with the late Gray Clegg, of Manchester, was instrumental in founding the North of England Ophthalmological Society; he became its Honorary Secretary and remained so until his death, combining the office with that of President in 1931-32. It was as Secretary of the North of England Society that Hay showed his genius for organisation. Regular Clinical Meetings were instituted at Manchester, Bradford, Leeds, Newcastle, Liverpool and Sheffield, and a first class Pathological service established. The outstanding success on such occasions as the joint meetings with the Midland Ophthalmological Society, the Scottish Ophthalmological Club, and the Royal Society of Medicine, was entirely due to his untiring efforts.

He was responsible for the annual lectures given to the North of England Society by men of the calibre of Van der Hoeve, Magitot, Gjessing, Von Rohr, Ronne, Goulden, Ballantyne, Duke-Elder, Traquair and Roaf. Perhaps his most outstanding success was the organisation of his famous tours-in 1935 it was Germany, Austria and Italy-in 1937 the Scandinavian countries, and in 1939 the U.S.A. and Canada, and had he lived he had other equally attractive plans maturing for future development. It was on these occasions that his ability as a linguist was so helpful and made all the difference to the smooth running of the programme; on one memorable occasion he was unexpectedly called upon to speak to a mixed audience in Sweden; he commenced in English, continued in French and German, and finished in Swedish. Also, one cannot forget the week-end which the Society spent in London as the guests of the Honorary Staff at Moorfields.

It can be truthfully said that Hay devoted his life to Ophthalmology. As Lecturer in Ophthalmology at the Sheffield University he was tireless in his efforts to improve the teaching facilities, both in the lecture room and at hospital, and he pressed hard for the founding of a Chair in Ophthalmology.

$\mathrm{He}$ was an indefatigable worker, hated slackness and had an uncanny instinct for picking out a genuine worker, to whom he would devote time and patience: He possessed a wide knowledge of ophthalmology and his medical and surgical colleagues rarely met him in consultation without picking up some new idea.

He contributed widely to ophthalmic literature and in 1929 he delivered the Richard Middlemore Lecture on "Astigmatism." 
He was a Vice-President of the Ophthalmic Section of the Royal Society of Medicine ; was a Past President of the local Division of the B.M.A., and a Past President of the Sheffield Medico-Chirurgical Society. In later years he achieved two of the highest honours which can come to a British Ophthalmologist-he became Master of the Oxford Ophthalmological Congress in 1939, and last year was elected President of the Ophthalmological Society of the United Kingdom. It will be a great disappointment to his ophthalmic colleagues that he was not spared to preside over the Society during the coming year.

Hay had many excellencies of character-industrious and careful in his work, with a vast store of scientific and clinical knowledge; wise in his counsels, and a perfect host with a sense of humour hidden behind a naturally shy disposition. He was a remarkably good photographer and very musical.

He leaves one daughter, Mrs. John Lane, his wife having predęceased him many years ago.

In spite of an outer reserve of character it was the privilege of many to know him well, and those who did, valued his friendship and cherish his memory.

\section{Mr. W. H. Kiep writes :-}

The North of England Ophthalmological Society has sustained an irreparable loss in the death of Percival J. Hay. He not only founded the Society but was very largely responsible for the smooth and successful running of it. I do not think any medical society has ever had a more zealous and kindly secretary. We all know that a secretary is largely responsible for the success or failure of a medical society. Percival Hay built up the Society stone by stone, and having first arranged clinical meetings at the various North of England cities, he later arranged for lecturers of distinction to come and deliver the "January. Lectures." Later on still, he organised tours, the first being to Hungary and Italy, the second to the Northern capitals and the last to America. The success of these tours can be judged by the fact that members of almost all other ophthalmological societies availed themselves of the opportunity to participate in the tour.

The outstanding characteristic of Percival Hay was that he would spare himself no effort to make the meetings a success and he would spend endless time in drawing up agenda or even. dinner plans in such a way as to secure the harmoniousness of the meeting. Anything that savoured of pungent criticism he sincerely deprecated, and was anxious that the members should all be on terms of friendship one with the other. Assuredly it may be said of him that he was a "gentle soul." 